\title{
INVENTORY OF THE ORCHIDS IN THE HUMID TROPICAL PREMONTANE FOREST ON UCHUMACHI MOUNTAIN, NOR YUNGAS REGION OF LA PAZ, BOLIVIA
}

\author{
Carlos A. Vergara Cassas \\ Universidad Católica Boliviana, Unidad Académica Campesina de Carmen Pampa, Coroico - Nor Yungas, \\ La Paz, Bolivia • betroven@googlemail.com
}

\begin{abstract}
RESUMEN. Para conocer la diversidad e importancia de las orquídeas en el bosque húmedo tropical premontano del Cerro Uchumachi (Nor Yungas, La Paz, Bolivia), se realizó un inventario de orquídeas durante 8 meses (febrero a septiembre de 2006) en un área aproximada a 80 ha, utilizando transectas lineales que ubican la principal en el camino carretero comprendido entre dos comunidades. Se establecieron 95 parcelas de $20 \mathrm{~m}$ x $20 \mathrm{~m}$, en las que se efectuaron la recolección, herborización, descripción botánica y taxonomía de las mismas. La búsqueda y recolección de orquídeas en las transectas dieron como resultado valores de: densidad absoluta, densidad relativa, y frecuencia. Se encontraron un total de 2159 orquídeas de 16 géneros y 31 especies, pero se crea que existen más que no han sido identificados por la falta de floración durante el tiempo del estudio. La especie de mayor densidad fue Epidendrum funckii con una densidad relativa de 33.72\%. Asimismo la especie que se presentó con más frecuencia en las parcelas fue Pleurothallis xantochlora con $22.11 \%$.
\end{abstract}

KEY WORDS: inventory, humid tropical premontane forest, cloud forest, Bolivia

\section{Introduction}

A greater of understanding of orchids in unstudied areas contributes to conservation, tourism and ecology in general. To understand the diversity of orchids in the premontane humid tropical forest area of Bolivia, an orchid inventory was conducted over 8 months (February to September 2006) in a cloud forest in northwestern Bolivia.

\section{Description of Study Area}

The geography of the region is formed from the eastern slopes of the Andes. The eco-region, called yungas, is characterized by mountain chains with wide slopes and long valleys formed from sedimentary and metamorphic rock. Altitudes range from 400 to 2800 meters above sea level (Morales, 2004).

The study area was comprised of primary and secondary forest. A small house was included in the secondary forest area, with a small plot of maize (Zea mays). Secondary forest had a great diversity of species, including tree ferns (Cyathea amazónica), "sikilis" (Inga sp), walnut (Juglans boliviana), "ambaibos" (Cecropia angustifolia), and diversity of ferns, mosses and palms. Secondary forest was char- acterized by a dense understory; there was also evidence of selective logging.

The transition between secondary and primary forest is evidenced by the presence of taller, higher-diameter trees, and a reduced understory due to a reduction of light to the forest floor. Evidence of human activity is also much reduced. This forest is dominated by tree ferns (Cyathea amazónica), individuals from the Lauraceae family, "espeke" (Clusia haughtii), "leche leche" (Sapium aereum), and "mata palo" (Ficus obtusifolia), that can reach diameters of over $100 \mathrm{~cm}$ and account for a large part of the basal area. Other species such as "jaluti" (Macrounea guianensis), "gironda" (Siparuna gesneroiodes), wild papaya (Oreopanax $\mathrm{sp}$ ) and "suti suti" (Miconia minutiflo$r a)$ are found at densities of one or less per hectare, indicators that they may be under the threat of extinction (Endara, 2001).

The forest soils are variable, with a 0 to $20 \mathrm{~cm}$ layer of organic matter. The soil closest to the surface is generally loamy with a predominance of silt $(39 \%)$, followed by sand (37\%) and clay (21\%). Soil structure is subangular blocky, friable when moist, with a relatively high organic matter content $(6.9 \%)$. 
Permeability is medium to high. Soil $\mathrm{pH}$ is very low (3.84 in $\mathrm{CaCl}_{2}$ ), and low cation exchange capacity $(7.4 \mathrm{cmol} / \mathrm{kg})$ (Villca, 2001).

Ten year average data from an on-site weather station show high average temperatures in January (above $19^{\circ} \mathrm{C}$ ) and low averages in June and July $\left(15^{\circ} \mathrm{C}\right)$, with registered maximum highs around $25^{\circ} \mathrm{C}$ and lows of $15^{\circ} \mathrm{C}$. Total annual precipitation is registered as $2390 \mathrm{~mm}$, with maximum precipitation in the months of December through April (200 to $300 \mathrm{~mm}$ per month) and no months with less than $80 \mathrm{~mm}$ per month. Relative humidity is $100 \%$ at night, and falls as low as $50 \%$ during the day.

\section{Methodology}

The study covered approximately 80 hectares (ha) of Uchumachi Mountain using linear transects extending out from the principal road between the communities of Carmen Pampa and Chovacollo in the municipality of Coroico, province of Nor Yungas, department of La Paz. Carmen Pampa is located at $16^{\circ} 20^{\prime} 30^{\prime \prime}$ South and $67^{\circ} 50^{\prime} 00^{\prime \prime}$ "West; the study plots ranged in altitude from 1880 to 2975 meters above sea level.

Orchids in 95 evenly spaced plots measuring $20 \mathrm{~m}$ by $20 \mathrm{~m}$ were collected, preserved and described. The transect plots, representing $4.75 \%$ of the 80 ha, yielded values for absolute densities, relative densities and frequencies for this site. Species identification was verified at the Herbario Nacional de Bolivia.

\section{Orchid Density}

A total of 2159 individual identifiable orchids from 16 genera and 31 species were found, and the presence of more species is suspected but not identified due to lack of flowers over the collection time (Table 1). This count yields an absolute density of approximately 568 orchids/ha.

The species Epidendrum funckii was the most abundant with 728 individuals and a density of 192 individuals/ha, and a relative density of $33.72 \%$. The next group, those with densities between 30 and 100 individuals/ha (and relative densities between 5 and 15\%), are Sobralia yauaperyensis, Sobralia fimbriata, Pleurothallis xanthochlora, and Restrepia antenifera. The remaining 26 species (Bletia catenulata, Elleanthus hookerianus, Epidendrum carpophorum, Epidendrum incisum, Epidendrum incisum, Epidendrum jajense, Epidendrum Secundum, Estelis sp1, Estelis sp2, Habenaria sartor, Koellenstenia boliviensis, Maxilaria aggregata, Maxilaria longicaulis, Maxillaria aurea, Notylia boliviensis, Oncidium tigratum, Oncidium mentigerum, Pleurothallis cordata, Pleurothallis heliconioides, Pleurothallis linguifera, Polystachia boliviensis, Scelochilus larae, Sobralia dichotoma, Sobralia dorbigniana, Sobralia sp, Sobralia suavolens and Zygopetalum intermedium) had densities of less than 20 individuals/ha, representing 630 of the 2159 individuals identified.

The presence of Epidendrum funckii in such great numbers implies that the environmental conditions are greatly favorable for its propagation, especially on road borders where it is adapted to the soil. In addition, the brush along roadsides is cleared twice per year, leaving the ground open to expansion, reducing competition from other plant species, and favoring access to sunlight. The species' sympodial growth character also favors its dispersion.

\section{Orchid Frequency}

The most frequent species in the plots was Pleurothallis xantochlora with $22.11 \%$, found in 21 of the 117 plots (Table 2). This species has a preference for moist forest areas, a characteristic of the primary and old-growth secondary forest in this study. It also has many flowers per plant which increases the chance of fecundation. It is also found in a variety of habitats, both high in the canopy and on fallen and rotting trunks.

Eight species fall into the intermediate category of frequencies of 5 - 16\%: Epidendrum funkii, Estelis sp1, Epidendrum secundum, Sobralia fimbriata, Sobralia yauaperyensis, Maxillaria aurea, Sobralia dichotoma and Estelis sp2. Two species, E. funckii and E. secundum, are always found in the same places, possibly due to their soil preferences; the other six species were all found along the roadside with the characteristics described above.

The remaining 22 species exhibited frequencies below 5\%. The least frequent were Elleanthus hookerianus, Epidendrum carpophorum, Maxilaria aggregata, Maxilaria longicaulis, Notylia boliviensis, Oncidium mentigerum, Pleurothallis heliconioides and Scelochilus larae with a frequency of $1.05 \%$ each. 
TABLE 1. Densities of orchids on Uchumachi Mountain, Nor Yungas, Bolivia.

\begin{tabular}{|c|c|c|c|}
\hline Species & Total plants encountered & Density (plants/ha) & Relative Density (\%) \\
\hline Epidendrum funckii & 728 & 191.58 & 33.72 \\
\hline Sobralia yauaperyensis & 284 & 74.74 & 13.15 \\
\hline Sobralia fimbriata & 221 & 58.16 & 10.24 \\
\hline Pleurothallis xanthochlora & 182 & 47.89 & 8.43 \\
\hline Restrepia antenifera & 114 & 30.00 & 5.28 \\
\hline Stelis sp. 1 & 73 & 19.21 & 3.38 \\
\hline Zygopetalum intermedium & 61 & 16.05 & 2.83 \\
\hline Sobralia sp & 54 & 14.21 & 2.50 \\
\hline Maxillaria aurea & 52 & 13.68 & 2.41 \\
\hline Stelis sp. 2 & 49 & 12.89 & 2.27 \\
\hline Sobralia dichotoma & 46 & 12.11 & 2.13 \\
\hline Bletia catenulata & 38 & 10.00 & 1.76 \\
\hline Polystachia boliviensis & 28 & 7.37 & 1.30 \\
\hline Epidendrum secundum & 27 & 7.11 & 1.25 \\
\hline Habenaria sartor & 26 & 6.84 & 1.20 \\
\hline Scelochilus larae & 24 & 6.32 & 1.11 \\
\hline Sobralia dorbigniana & 24 & 6.32 & 1.11 \\
\hline Pleurothallis linguifera & 21 & 5.53 & 0.97 \\
\hline Sobralia suavolens & 19 & 5.00 & 0.88 \\
\hline Oncidium tigratum & 17 & 4.47 & 0.79 \\
\hline Epidendrum jajense & 13 & 3.42 & 0.60 \\
\hline Epidendrum incisum & 9 & 2.37 & 0.42 \\
\hline Koellenstenia boliviensis & 9 & 2.37 & 0.42 \\
\hline Notylia boliviensis & 9 & 2.37 & 0.42 \\
\hline Oncidium mentigerum & 8 & 2.11 & 0.37 \\
\hline Maxilaria aggregata & 6 & 1.58 & 0.28 \\
\hline Pleurothallis cordata & 5 & 1.32 & 0.23 \\
\hline Pleurothallis heliconioides & 4 & 1.05 & 0.19 \\
\hline Elleanthus hookerianus & 3 & 0.79 & 0.14 \\
\hline Maxilaria longicaulis & 3 & 0.79 & 0.14 \\
\hline Epidendrum carpophorum & 2 & 0.53 & 0.09 \\
\hline TOTAL & 2159 & 568.16 & 100.00 \\
\hline
\end{tabular}

\section{Conclusion}

Information about density, frequency, habitat and flowering times is useful for planning for tourism activities, which are growing in importance in this area of Bolivia. This information can be used to create eco-tourist paths through the cloud forest for observation and education. Inventory data is also useful to justify conservation activities as slash and burn agriculture encroaches more and more into these environments. Inventories also increase the potential for preservation of orchid germplasm, and tissue culture can be considered to raise and sell the more mar- ketable species found without creating an imbalance in the ecosystem from which the species originate.

ACKNOWLEDGEMENTS. I would like to extend my thanks to my advisor Dr. Carol Wake at South Dakota State University, the Belgian Embassy/CTB for economic support, the Director of the Unidad Académica Campesina de Carmen Pampa Sr. Damon Nolan, Director of the Agronomy Department José Luis Beltrán, Dr. Hugh Smeltekop, Dr. Paul Johnson (SDSU), Roberto Vasquez Chavez for taxonomic help, the Director of the Herbario Nacional de Bolivia Dr. Stephan Beck and Fabricio Miranda and other members of the Herbario, and my mother Carolina Cassas Navia. 
TABLE 2. Frequencies of orchids on Uchumachi Mountain, Nor Yungas, Bolivia.

\begin{tabular}{l|c|c} 
Species & No. plots where sp was found & Frequency (plots with sp/total plots) (\%) \\
\hline Pleurothallis xanthochlora & 21 & 22.11 \\
\hline Epidendrum funckii & 15 & 15.79 \\
\hline Estelis sp1 & 15 & 15.79 \\
\hline Epidendrum secundum & 14 & 14.74 \\
\hline Sobralia fimbriata & 12 & 12.63 \\
\hline Sobralia yauaperyensis & 9 & 9.47 \\
\hline Maxillaria aurea & 8 & 8.42 \\
\hline Sobralia dichotoma & 6 & 6.32 \\
\hline Estellis sp2 & 5 & 5.26 \\
\hline Sobralia suavolens & 4 & 4.21 \\
\hline Epidendrum jajense & 3 & 3.16 \\
\hline Pleurothallis cordata & 3 & 3.16 \\
\hline Pleurothallis linguifera & 3 & 3.16 \\
\hline Bletia catenulata & 2 & 2.11 \\
\hline Epidendrum incisum & 2 & 2.11 \\
\hline Habenaria sartor & 2 & 2.11 \\
\hline Koellenstenia boliviensis & 2 & 2.11 \\
\hline Oncidium mentigerum & 2 & 2.11 \\
\hline Polystachia boliviensis & 2 & 2.11 \\
\hline Restrepia antenifera & 2 & 2.11 \\
\hline Sobralia dorbigniana & 2 & 2.11 \\
\hline Sobralia sp & 2 & 2.11 \\
\hline Zygopetalum intermedium & 2 & 2.11 \\
\hline Elleanthus hookerianus & 1 & 1.05 \\
\hline Epidendrum carpophorum & 1 & 1.05 \\
\hline Maxilaria aggregata & 1 & 1.05 \\
\hline Maxilaria longicaulis & 1 & 1.05 \\
\hline Notylia boliviensis & 1 & 1.05 \\
\hline Oncidium tigratum & 1 & 1.05 \\
\hline Pleurothallis heliconioides & 1 & 1.05 \\
\hline Scelochilus larae & 1 & 1.05 \\
\hline TOTAL & 2 & $\mathbf{1 0 0 . 0 0}$ \\
\hline & 2 & \\
\hline & 2 & \\
\hline & 2 & \\
\hline
\end{tabular}

\section{LiteratuRe Cited}

Endara, A.R. 2001. Inventario de las especies forestales del bosque húmedo tropical premontano del Cerro Uchumachi sector Carmen Pampa. Tesis De Grado. Universidad Católica Boliviana - Unidad Académica Campesina de Carmen Pampa. La Paz, Bolivia.

Morales, C. B. 2004. Manual de ecología. 2a Edición.
Editorial Instituto de Ecología, Universidad Mayor de San Andrés. La Paz, Bolivia.

Villca H., R. 2001. Evaluación de la erosión hídrica en un sistema agroforestal café (Coffea arabica) con sikili (Inga adenophylla) bajo dos métodos de control de maleza con chonta y machete en Carmen Pampa. Tesis de grado. Universidad Católica Boliviana - Unidad Académica Campesina de Carmen Pampa. La Paz, Bolivia.

Carlos Alberto Vergara Cassas was born in La Paz, Bolivia, and received his B.S. at the Unidad Académica Campesina de Carmen Pampa, a rural campus of the Catholic University of Bolivia in the yungas region of La Paz. His thesis was an inventory of orchids in the cloud forest near the university. He has participated in courses and workshops about orchid conservation in Bolivia, and has worked with orchids in Bolivia's Cotapata National Park. 